\title{
An Approach Towards Application of Semiconductor Electronics Converters in Autonomous DFIM Based Wind Energy Generation System: A Review
}

\author{
Venktesh Mishra*, Rishabh Dev Shukla**, Premnath Gupta*** \\ *Electronics and Communication Engineering, J.K. Institute of Applied Physics and Technology,University of \\ Allahabad,Prayagraj - 211002 India \\ **Electrical Engineering, Budge Budge Institute of Technology Kolkata, West Bengal, -700137 India
}

\begin{abstract}
***Electronics and Communication Engineering, J.K. Institute of Applied Physics and Technology, University of Allahabad,
\end{abstract} Prayagraj - 211002 India

(venkateshalld@gmail.com, shukla.rishabhdev@gmail.com,pngjkaaau@yahoo.co.in)

Received: 09.07.2019 Accepted:10.08.2019

\begin{abstract}
This paper gives an approach towards the application of different semiconductor electronics converters in area of autonomous DFIM based wind energy generation system. For the operation of autonomous DFIM based wind energy system different control techniques are used which depends on the actual position and speed of rotor. Various control methods are given as stator flux oriented control methods; direct voltage control methods and MRAS observer based methods. These methods are usually applicable in autonomous DFIM based variable speed wind energy generation system.
\end{abstract}

Keywords Autonomous DFIM (Doubly Fed Induction Machine), semiconductor electronics converter,voltage source inverter, wind energy system.

\section{Introduction}

From the last 2-3 decades, economic atmosphere of the whole world depends on the renewable energy sources. Wind energy is a clean and eco-friendly renewable energy resource, which reduces dependency from fossil fuels. Wind energy system plays a very significant role to become more reliable renewable energy source across all over the world. The demand of wind energy increases gradually. At the end of 2020; it is expected that demand of wind power may be reaches up to $75 \mathrm{GW}$ [1]. In fixed wind speed systems squirrel-cage induction generators are used, which is directly connected with grid system [4] as in case of variable wind speed [2]-[18].This review paper focused on actual position of the rotor and speed sensorless control method operation in autonomous DFIM based wind energy generation system
[19]-[37]. In such system to control the variable-speed operation direct voltage control methods [37]-[55]; stator flux oriented control methods [72]-[74]; and MRAS observer based methods [90]-[103] are used. For higher wind velocity, active pitch angle control method is used to overcome the generated aerodynamic power by changing the actual position of rotor blades through suitable angle from wind direction. To resolve the problem of high wind speed operation, wind turbines are fabricated using power control scheme. Primary techniques used for power control [21] in wind turbines systems are: - a) Pitch controlled b) Stall controlled c) Active stall controlled d) Yaw controlled.

In case of pitch controlled wind turbine system an electronic regulator is used for continuous observation of wind turbine output power. An actuating signal is generated 
when the output power cross the threshold limit and send this actuating signal to the blade pitch mechanism for immediately pitching (turning) the rotor blades marginally out of the wind. On the other hand when the output power again within the threshold limit due to moderate or low wind speed, the blade pitch mechanism again turning or pitching back the turbine blades in the direction of wind. Thus turbine blades are capable enough to move or turn pitch with reference to their longitudinal axis. Normally at a time, a small degree of turn will be given to the turbine for moving rotor blades in case of pitch controlled wind turbines. In stall controlled based wind turbines; the rotor blades bolted on head of the hub with a fixed angle. In stall controlled wind energy system, moving towards its longitudinal axis, the rotor blades distort fairly. The output power is controlled through the design of rotor blades. In case of $1 \mathrm{MW} \&$ above rated wind energy systems, active stall control is preferred more. It is quite similar as pitch controlled mechanism, having pitchable blades operate through either hydraulics or electric stepper motors. In case of active stall control, the output power is more precise as obtained in case of passive stall. The machine can also be run near to rated power for every permissible wind speeds. In case of tiny wind turbines (1 $\mathrm{kW}$ or less), Yaw control technique is used [13][22].Section II shows the basics of wind energy generation systems and various semiconductor electronics converters used in variable wind speed operation are discussed here. Section III provides brief review about autonomous DFIM based wind energy generation system, and Section IV contain control techniques used in autonomous DFIM based wind energy generation system. Section V consists of complete conclusions of the above.

\section{Basics of Wind Energy Generation System}

Fundamental components of a wind turbine system are presented in Fig. 1. It consists of wind turbine, gearbox, generator, semiconductor electronics converter, coupling transformer for grid connection. Wind is main source of power for wind turbines operation; depends on the structure of the rotating blades which converts wind power into revolving mechanical power [9].

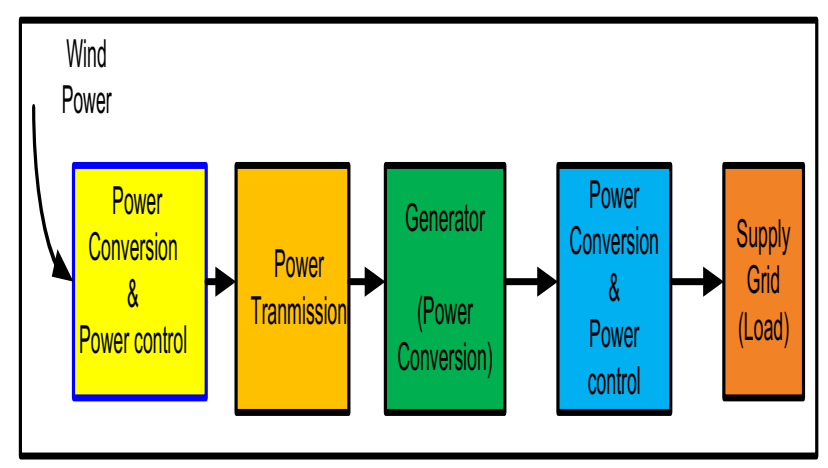

Fig.1. Basic elements of a Wind Energy Generation System

As per the revolving speed, it is categories as: - variable speed wind energy system and fixed speed wind energy system. Variable speed DFIM based wind energy generation system having a wound rotor induction generator \& semiconductor electronics converter on the rotor side. Its operation can be presented in to four quadrant systems and having capability of supplying and consuming active and reactive power from the grid. A more detailed about the operating modes of the DFIM based wind energy system is shown in Figure 2.

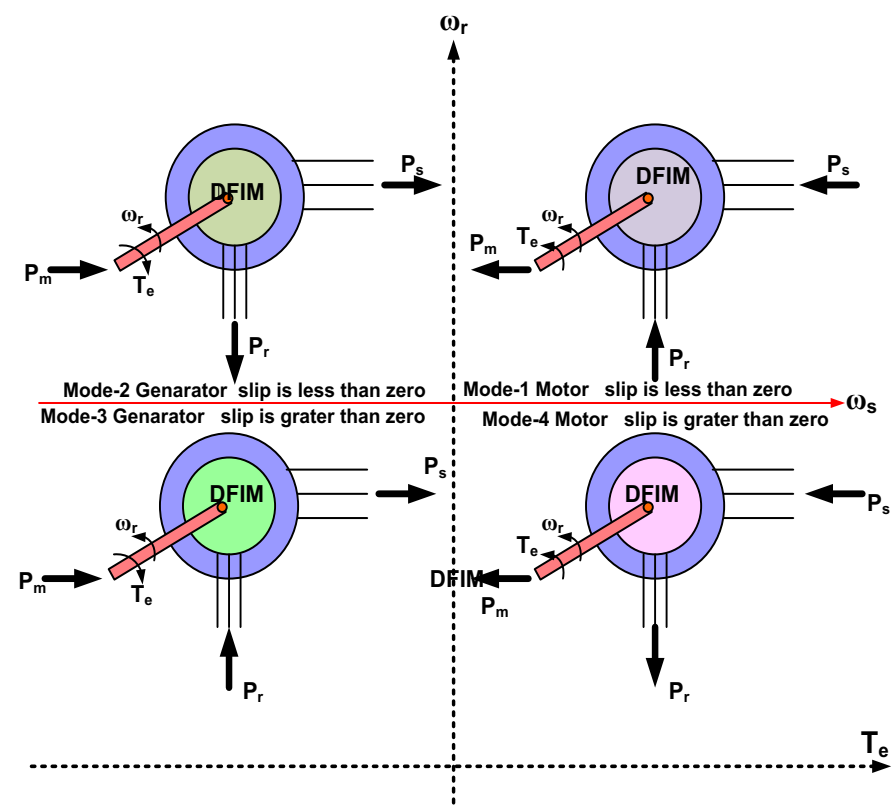

\begin{tabular}{|l|c|}
\hline $\mathrm{P}_{\mathrm{r}}$ \& & $\begin{array}{r}\text { Up \& Left arrow---- Power received by the machine } \\
\text { (s for stator and } \mathrm{r} \text { for rotor) }\end{array}$ \\
\hline & $\begin{array}{r}\mathrm{P}_{\mathrm{s}} \\
\text { (s for stator and } \mathrm{r} \text { for rotor) }\end{array}$ \\
\hline $\mathrm{P}_{\mathrm{r}} \rightarrow-\mathrm{P}_{\mathrm{s}}$ & $\begin{array}{r}\text { Down \& Right arrow---Power generated by the machine } \\
\text { Right arrow----Mechanical Power supplied to the machine }\end{array}$ \\
\hline$\omega_{\mathrm{s}} \omega_{\mathrm{r}} \mathrm{T}_{\mathrm{e}}$ & Left arrow----Mechanical Power delivered by the machine \\
\hline
\end{tabular}

Fig. 2. Different possible operating modes of DFIM system

It has two operating modes such as Sub-synchronous; Super-synchronous. This mode of operation depends on the angular speed of rotor with respect to synchronous speed. Fully controlled semiconductor electronics converters are used to control rotor current injection in case of sub and super synchronous modes. In super synchronous mode, angular speed of rotor is slower than synchronous speed. Real power is drawn from the stator/grid (or any other external source) and delivered to the rotor via semiconductor electronics converter where as in case of sub synchronous mode; rotor angular speed is greater than synchronous speed. Power is generated in rotor (in addition to power generated in the stator) and delivered to the grid/load via semiconductor electronics converter. In such type of system gear boxes are used to maintain lower shaft speed to higher speed; acceptable in case of DFIM based wind energy generation system. Variable speed wind energy system can be 


\section{Mishra et al., Vol.3, No.3, September, 2019}

categorized on behalf of power rating of the semiconductor electronics converters. In power generation the role of power rating of converters are very important. In wind energy generation system full-scale and partial-scale semiconductor electronics converters are used for power generation.

\subsection{Variable speed wind energy system using full-scale or full rated semiconductor electronics converter}

The concept of variable wind speed energy system with fullscale semiconductor electronics converters are used in synchronous generators and squirrel cage induction generator system. A full rated semiconductor electronics converter is connected in between generator and grid. It is connected in back-to-back position in between two voltage source converter with a common capacitive dc link. This system is used to control the generated active and reactive power from the grid in bidirectional nature [57]-[60]. In the synchronous generator at the generator end, bridge rectifier may be used but the overall system in not completely controlled i.e. to achieve the maximum power point tracking, generator speed is not properly regulate as per wind speed [25]. When generator is separated from the grid, a large scope of frequency/speed is feasible for optimal operation. Enhancing of the dynamic response of the system and separately control of active and reactive power can be done through grid-side converter. Fig. 3 shows different feasible design of variable speed wind energy generation system using full-scale semiconductor electronics converters [27].

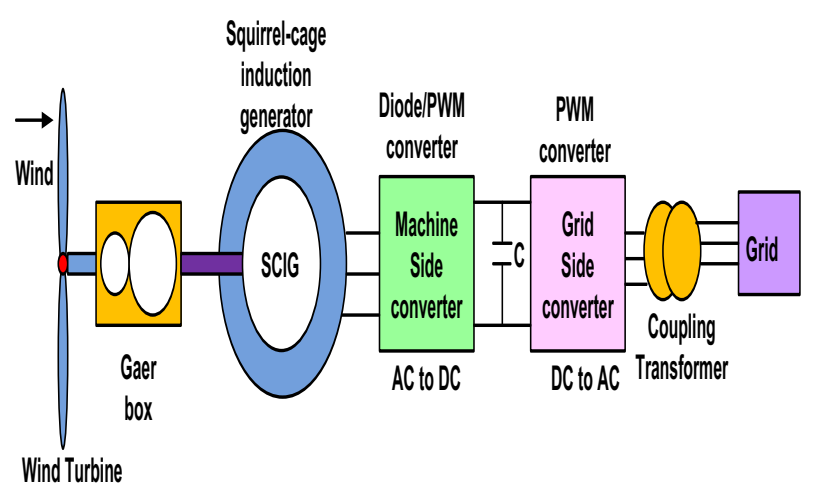

(a)

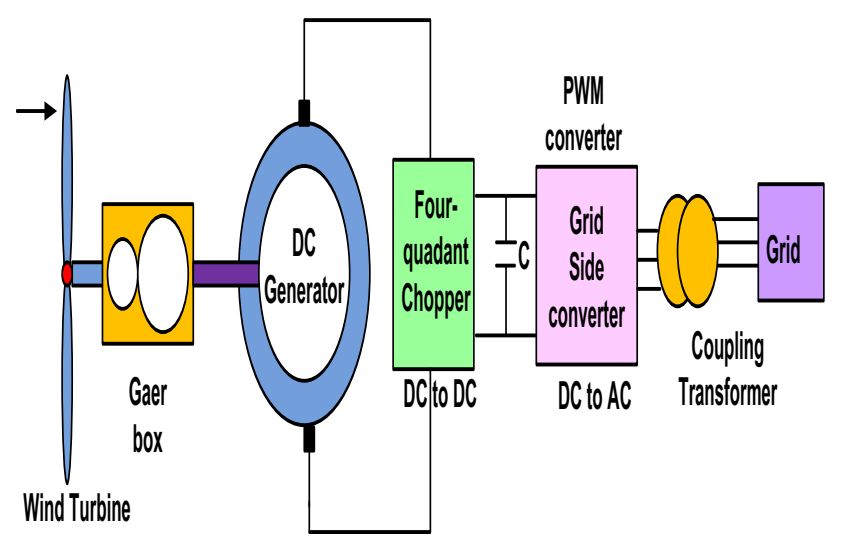

(b)

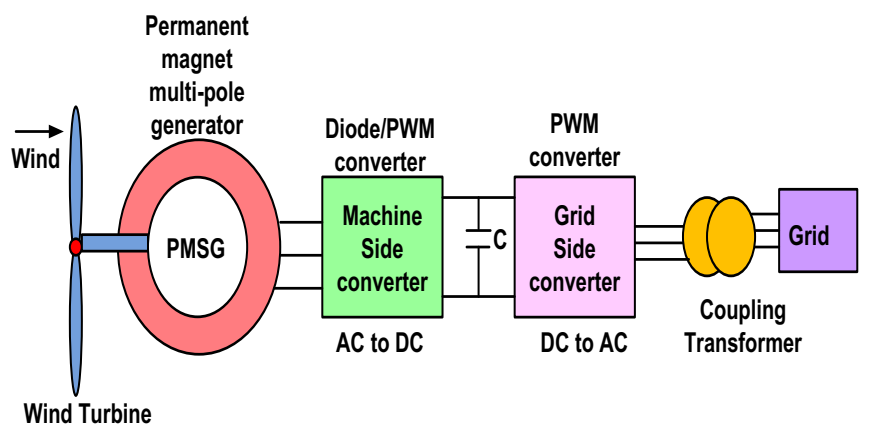

(c)

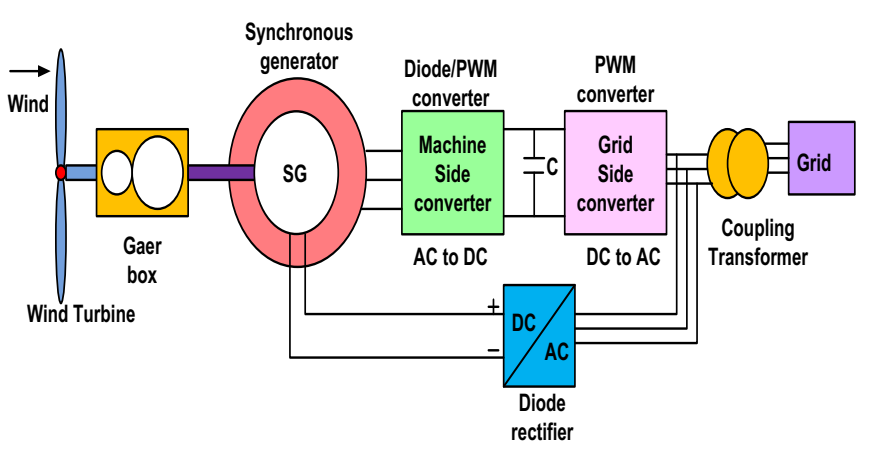

(d)

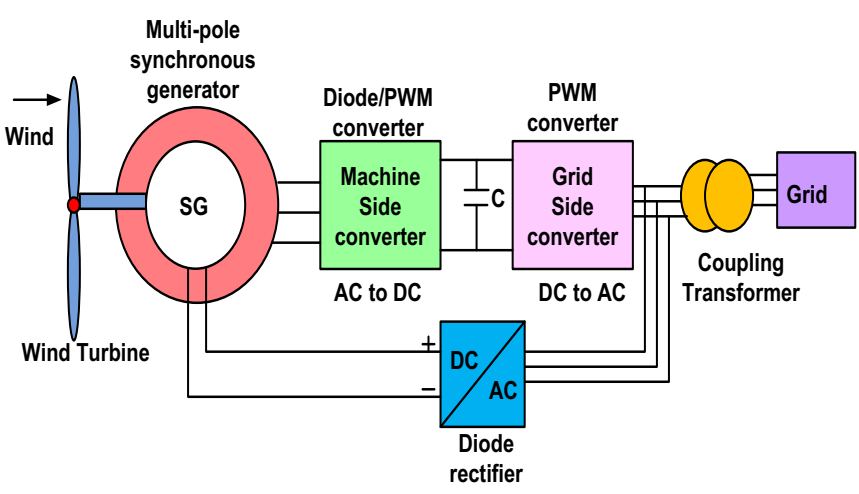

(e)

Fig. 3. Schemes for variable-speed full-scale semiconductor electronics converter based wind energy generation system (a) by using squirrel cage induction generator (b) by using dc generator (c) by using synchronous generator (d) by using multi-pole synchronous generator (e) by using permanent magnet multi-pole generator

The various possible configurations depend on the variable wind speed based wind energy generation system using squirrel cage induction generator is given in Fig. 3a. In this configuration stator is connected through grid with backto-back connected 3-level voltage source semiconductor electronic bridge converters [57]. The power rating of stator defines the actual size of power converter which is capable to covert generated wind power into stator power. Designing of gearboxes are done in such a manner that the maximal speed of rotor corresponds to estimate speed of the generator. The 
main advantage of variable speed configuration is to better utilization of available wind power and to reduce the necessity of capacitor bank. The available capacitor banks used to draw reactive power from grid [54]. Major drawback of this configuration is higher cost and more losses with full scale converter. The overall performance of system (gearbox, induction generator and converter) may be reduced. In this configuration, shown in Fig. $3 \mathrm{~b}$ instead of classically used alternating current based machine, permanent magnet based dc generator is used for providing conversion of energy using wind energy generation system. Due to cause of simple design, dc machine has been selected for operation, but ratings and limited speed operation are the main drawback of this configuration. Moreover dc machines have well known demerits in reference to power generation.

The grid connected variable speed Permanent Magnet Synchronous Generator (PMSG) based wind energy system is given in Fig. 3c. Here PMSG may be used as a generator because of smaller in size. Due to cause of self excitation property, PMSG play a significant role in wind energy technology, which allows an operation at high power factor and higher efficiency. Additionally, PMSG has shown inherent economic and technical advantages, such as in the absence of field losses, PMSG have better thermal characteristics, higher reliability, large power to weight ratio and better dynamic stability [51]. Nevertheless, PMSG have some drawbacks such as: higher material cost; difficulties in handling during construction, demagnetization at high temperature.

In general for low power application PMSG is used but in larger systems synchronous generator may also be used. The synchronous generator which is excited electrically, designed through a rotor carrying dc excitation field windings. The 3-phase winding of stator is similar to induction machine which does not depend on type of poles of rotor. In case of low speed synchronous generator system, salient pole based field system are more reliable for wind energy generation system. A grid connection scheme of electrically excited synchronous generator based wind energy system is indicated in Fig. 3d. In this system, gear box can be removed through multi-pole machine as shown in Fig. 3e. They all are applicable for full scale or fully estimated semiconductor electronics converters, which minimize the manufacturing cast and overall performance of the system.

\subsection{Variable speed wind energy system using partial-scale or partial rated semiconductor electronics converter}

DFIM is applicable for variable speed wind turbine systems which having a wound rotor induction generator and semiconductor electronics converter connected at rotor side represented in Fig. 4a. It operates into four different quadrant systems, which are used for supply and absorbing the active and reactive power connected through grid. Depending on the rotor speed in may be operated into two different modes known as sub-synchronous and super-synchronous [26][28].These operating modes dependent on angular speed of rotor which depends on synchronous speed. Fully controlled semiconductor electronics converters are used for controlling of the rotor current injection in sub-synchronous and supersynchronous mode. In sub-synchronous mode, rotor speed is less than synchronous speed thus real power can be drawn from the stator/grid (or any other external source) and delivered to the rotor via semiconductor electronics converters as shown in Fig. 4b. In case of super-synchronous mode of operation, the rotor speed is greater than the synchronous speed hence power generated in rotor (in addition to power generated in the stator) and supply to the grid/load via semiconductor electronics converters given in Fig. 4b. DFIM based wind energy generation system having number of gear box are used to increase the rotational speed of wind turbine shaft to generate electrical power for DFIM operation.

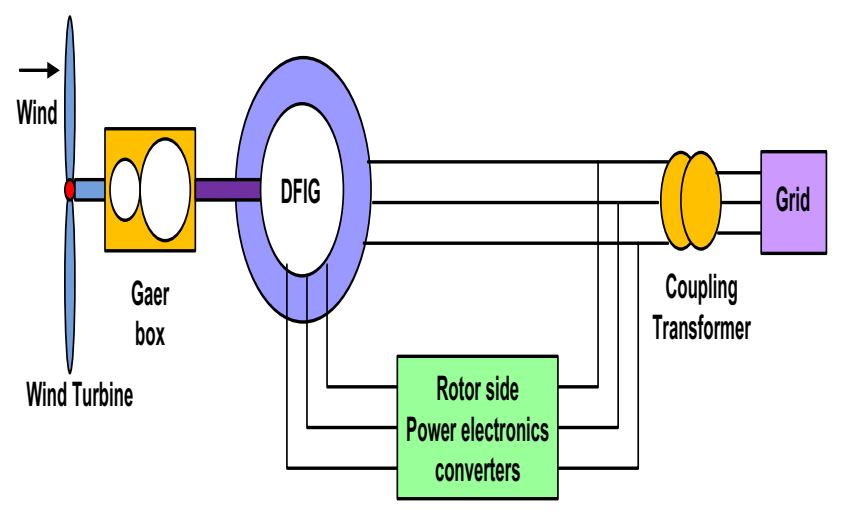

(a)

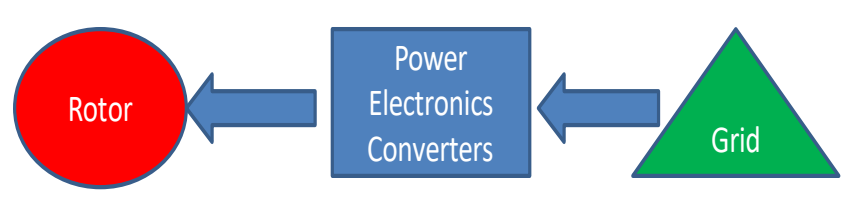

Sub-synchronous speed operational mode

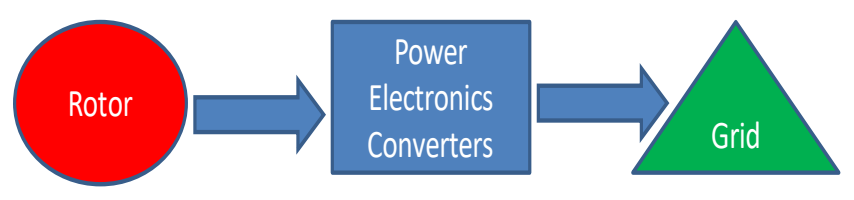

Super-synchronous speed operational mode,

(b)

Fig. 4. (a) Scheme of a variable speed concept with DFIM based wind energy generation system (b) Power flow direction under the sub-synchronous and super-synchronous modes

DFIM having a wide operational speed range which actually depend on the actual rating of semiconductor electronics converter. In this mode of operation the allowable speed ranges exist from $+30 \%$ to $-30 \%$ near to synchronous speed [21].The power generation capacity of semiconductor electronics converter is up to $25-30 \%$ depending on the converter rating, which is very essential from an economic 
point of view. Various topologies for DFIM [44]-[48], given as partial-scale power converter consist of back to back PWM converters, conventional AC-AC converter, and matrix converter or hybrid current-source/voltage source power converters [18].

\section{Autonomous operation of DFIM based wind energy generation system}

In case of autonomous DFIM based wind energy generation system; stator is not directly connected through grid. In this mode of operation stator connected through an isolated load. Fig.5 shows fundamental block diagram of an autonomous DFIM based wind energy generation system connected via an isolated load.

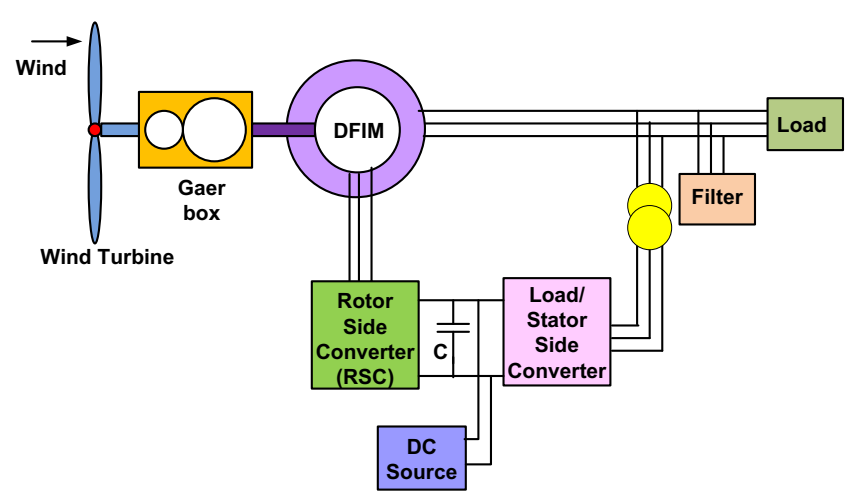

Fig. 5. DC source supported autonomous DFIM based wind energy generation system.

In case of DFIM based wind energy generation system, gear boxes are used for low to high speed operation of rotor shaft. Rotor is connected through the load via semiconductor electronics converters. The bidirectional power flow is possible because of back-to-back connected voltage source converters through a common capacitive dc link. It is defined as rotor side converter and stator/load side converter. For initial excitation of generator a dc battery is required.

\section{Control of Autonomous DFIM based Wind Energy Generation System}

For the regulation of voltage and frequency towards customers end, an autonomous DFIM based wind energy generating system is used. There exist a technique for proper monitoring and controlling of amplitude and frequency of output voltage at the load end. Direct voltage control and stator flux oriented control are two fundamental methods for controlling the voltage and frequency of autonomous DFIM based wind energy generation system. The operation of direct voltage control is easier than stator flux oriented control. In case of direct voltage control, no any message signal available from mechanical sensors for detection of angle position or rotor speed. Speed sensorless techniques are used for controlling the voltage and frequency for autonomous DFIM based wind energy generation system, as discussed in the literature such as direct voltage control techniques [37]-[55], stator flux oriented techniques [72][74], MRAS (Model Reference Adaptive System) observer based techniques [90]-[103]. All the existing control techniques have their own merits and demerits, but in real time as per implementation point of view these techniques are very complex in design using various softwares as well as hardware platforms.

\subsection{Indirect/stator flux oriented control technique}

Ignoring the stator resistance and imposing slip frequency to the rotor currents, indirect/stator flux oriented control technique are used to control stator voltage and frequency. Generated stator flux is used for evolution of stator and rotor currents. In this techniques stator flux orientated reference frame are used to maintain load voltage and frequency constant. Evaluated speed/angle is given by synchronization of estimated and measured stator flux; estimated stator flux is used to measure stator and rotor currents. For the regulation of amplitude of stator voltage, current magnetization control technique is used.

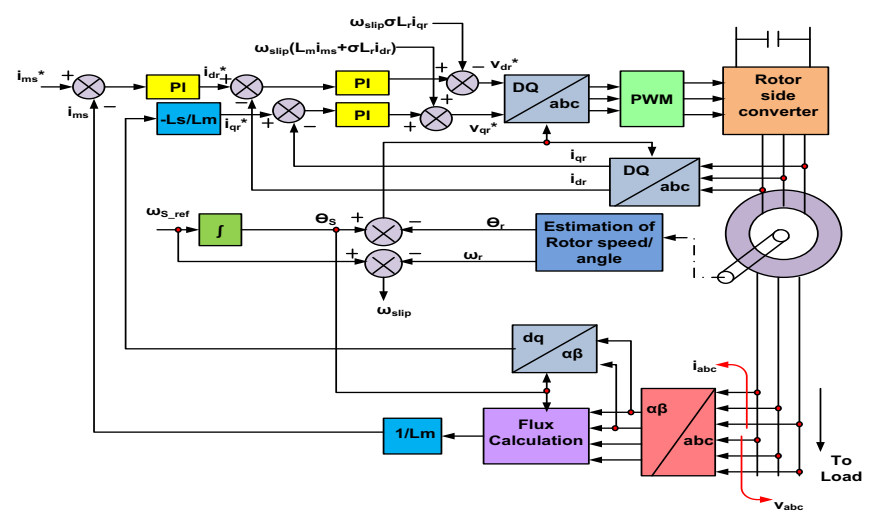

Fig. 6. Block diagram of indirect voltage and frequency control scheme.

\subsection{Direct voltage control (DVC) technique}

Direct voltage control technique is established on the stator voltage space vector representing through a synchronous (or stator frequency) rotating frame. Here the stator voltage is regulated by rotor current magnitude and frequency at the stator terminal is depending on rotor current frequency and mechanical speed of the rotor. Firstly, the three phase stator voltage is sensed and converted into $V_{d}$ and $\mathrm{V}_{\mathrm{q}}$ using the synchronously (i.e. desired/reference stator frequency) rotating reference frame, after that the stator voltage magnitude $\left(=\sqrt{ }\left(\mathrm{V}_{\mathrm{d}}^{2}+\mathrm{V}_{\mathrm{q}}^{2}\right)\right)$ and angle $\left(=\tan ^{-1}\left(\mathrm{~V}_{\mathrm{q}} / \mathrm{V}_{\mathrm{d}}\right)\right)$ is calculated. Reference magnitude of rotor currents is generated through magnitude regulator (i.e. a PI controller), which is operating on an error calculated in between reference stator voltage magnitude and actual calculated stator voltage magnitude. Similarly, the speed regulator (i.e. a PI controller) gives reference rotor speed which is operating on an error calculated in between reference stator voltage vector position (i.e. zero) and actual calculated stator voltage vector position. After integrating the obtained rotor reference speed, reference angle is obtained at the converter end to convert these polar quantities (i.e. reference 
magnitude and angle) into three phase quantities. On comparing the reference rotor currents with measured one, error signals are generated which generates the PWM signal for rotor-side semiconductor electronics converter. This DVC technique ensures that the constant stator voltage vector magnitude and its position angle are used to give the constant voltage magnitude, frequency and controlled phase voltage.

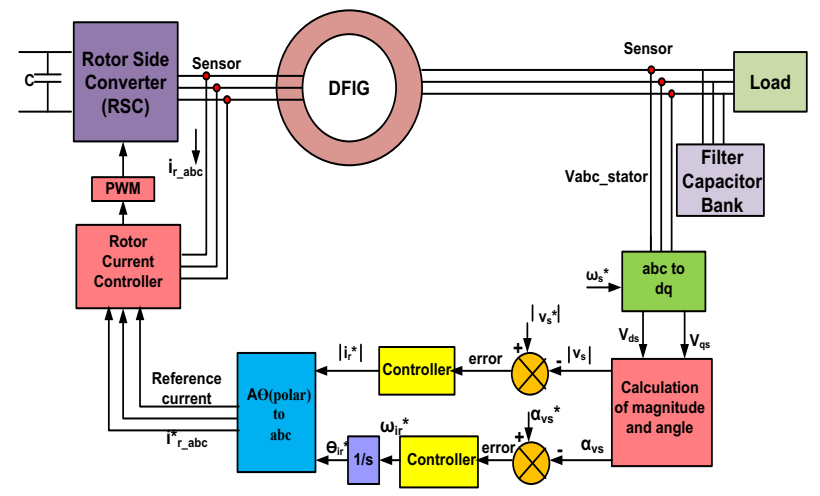

Fig. 7. Direct voltage control method

\subsection{MRAS Observer based control technique}

In case of cage induction machines the Model Reference Adaptive System (MRAS) method is recognized for sensorless control. Few data required for the application of MRAS observers in case of sensorless control of autonomous DFIM based wind energy generation system. Open loop types of observer are suitable for estimation of error uncertainties present in the model. Whereas closed loop observers are more efficient in case of steady state and transient type of control system [68]. For estimation of rotational speed and rotor position of DFIM, MRAS speed observer is used. Different types of MRAS observers are Stator-flux-based MRAS observer, Stator current based MRAS observer, Rotor current based MRAS observer, Rotor flux based MRAS Observer, Reactive power based MRAS Observer. In Rotor flux based sensorless control; rotor flux is obtained by the integration of the rotor back-electromotive force. When it operates near to synchronous speed, rotor excitation occurs at low frequency thus its performance reduces due to cause of integration problem available in the system.

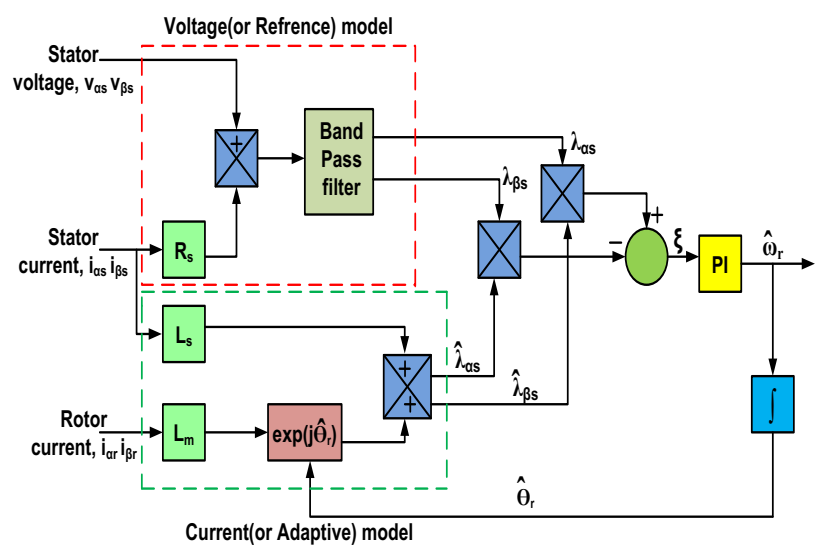

(a)

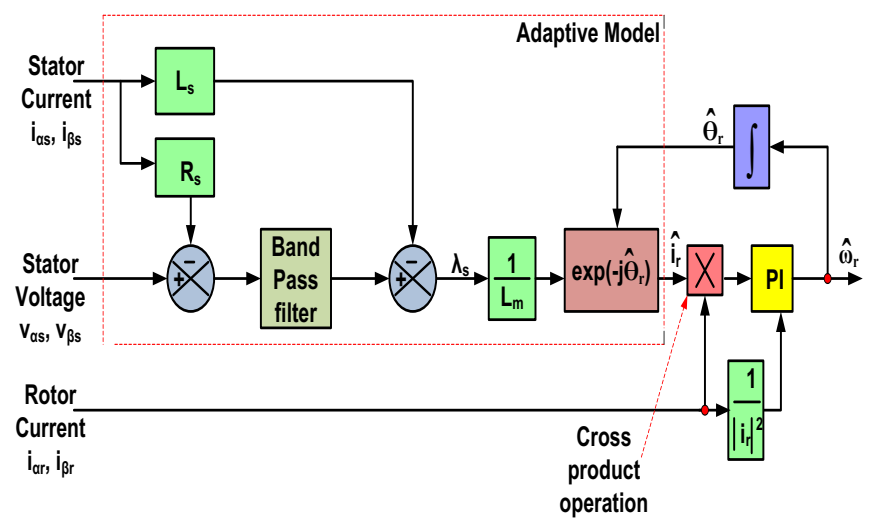

(b)

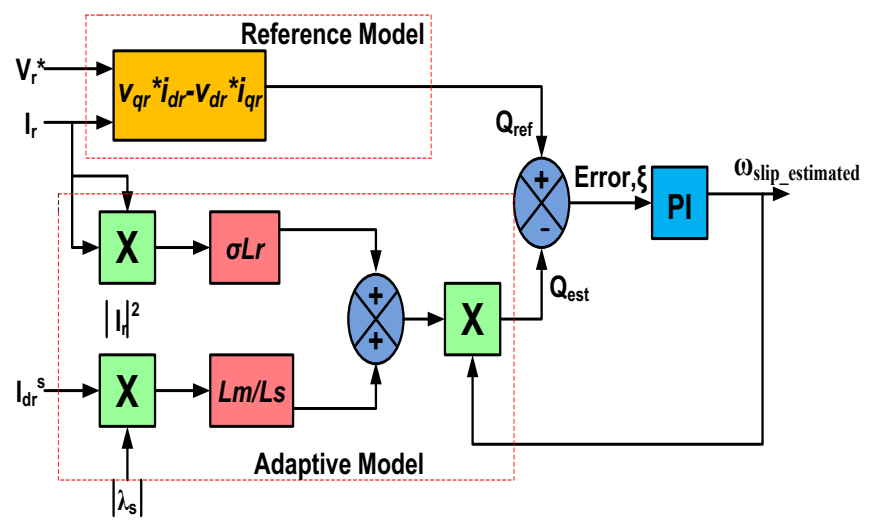

(c)

Fig. 8. (a) Stator-flux-based MRAS observer (b) Rotor current based MRAS observer (c) Reactive power based MRAS Observer (Q-MRAS)

In stator flux based MRAS observer, flux obtained from the voltage model used as reference flux. By adjusting the estimated rotational speed, generated error in between reference flux and estimated flux is given to PI controller which provides the estimated rotational speed. In case of rotor current based MRAS observer, rotor speed and position are estimated using the rotor current. This current can be obtained from direct measurements through transducers. This current is compared with an estimated rotor current obtained from the stator voltage. PI controllers are used for processing the error which gives the estimated speed for correcting the estimation of the rotor position and speed. This primary model for reactive power based MRAS observer having a reference model which computes the instantaneous rotor side reactive power. An adaptive model is used to give the steady state reactive power. Generated error is processed through a PI controller and output signal provides estimated slip speed. This estimated slip speed is used to tune the adaptive model such that error minimized to be zero. The Q-MRAS is suitable for speed catching operation, but it gives incorrect 
results of speed estimation when the direct-component of rotor current is varied.

\section{Conclusion}

A review on the application of semiconductor electronics converters in autonomous DFIM based wind energy generation system has been presented and discussed here. Different generators and semiconductor electronics converters used in variable speed wind energy generation systems are also reviewed and discussed in brief to give more insight about the concerned topic. Variable speed DFIM based wind energy generation system has shown dominance in the wind energy market largely because of the fractional power rating $(25 \%-30 \%)$ of semiconductor electronics converter system. Autonomous/stand-alone DFIM based wind energy generation system has been presented and discussed where the control of voltage and frequency at stator terminal is the main subject of concern. Using the proposed control technique, the stator voltage and frequency are balanced and constant at their reference values. Different techniques to control the autonomous DFIM based wind energy generation system has been summarized and discussed. The proposed techniques may be valid for both linear and non-linear loads. Future work will concern the laboratory tests of the proposed techniques in the paper.

\section{References}

1. Annual Report 2017-2018, Ministry of New and Renewable Energy, https://mnre. gov.in/filemanager/annual-report/2017-2018/EN/pdf/chapter13.pdf, Accessed date: 28 October 2018.

2. R. Bansal and A. Zobaa, "Handbook of renewable energy technology".

3. T. Ackermann, L. Soder, "Wind energy technology and current status: a review", Renewable and Sustainable Energy Reviews 2000;4(4):315-74.

4. Frede Blaabjerg, Marco Liserre, Ke Ma, "Power Electronics Converters for Wind Turbine Systems", IEEE Transactions on Industry application, vol. 48, Issue: 2 pp. $708-719,2012$.

5. Abdul Motin Howlader, Naomitsu Urasaki, Atsushi Yona, Tomonobu Senjyu, Ahmed Yousuf Saber, "A review of output power smoothing methods for wind energy conversion systems", Renew. Sustain. Energy Rev., vol. 26, pp. 135-146, Oct. 2013.

6. H. T. Jadhav, R. Roy, "A critical review on the grid integration issues of DFIG based wind farms", Proc. 10th Int. Conf. Environ. Elect. Eng., pp. 1-4, 2011.

7. Bahadur Singh Pali, Shelly Vadhera, "Renewable energy systems for generating electric power: A review", Power Electronics Intelligent Control and Energy Systems (ICPEICES)IEEE International Conference on, pp. 1-6, 2016.
8. CN Rasmussen, "Improving wind power quality with energy storage", In: Conference on sustainable alternative energy (SAE), 2009 IEEE PES/IAS, Institute of Energy Technology. Aalborg, Denmark: Aalborg University; 2009. pp. 1-7.

9. B. Wu, Y. Lang, N. Zargari, S. Kouro, Power Conversion and Control of Wind Energy Systems. Hoboken, NJ: Wiley, 2011.

10. S.Yuvarajan, Lingling Fan, "A Doubly-Fed Induction Generator-Based Wind Generation System with quasisine rotor injection", Journal of Power Sources, vol.184, pp.325-330, 2008.

11. J. M. Carrasco, L. G. Franquelo, J. T. Bialasiewicz, E. Galvan, R. Portillo, M. M. Prats, J. I. Leon, and N. Moreno-Alfonso, "Power electronic systems for the grid integration of renewable energy sources: A survey," IEEE Trans. Ind. Electron., vol. 53, no. 4, pp. 1002-1016, Jun. 2006.

12. N. Mohan, T. M. Undeland, and W. P. Robbins, Power Electronics: converters, applications and design, 3rd edition, J. Wiley \& Sons, 111 River Street, Hoboken, NJ 07030-5774, US, 2003.

13. O. Carlson, J. Hylander, K. Thorborg, "Survey of variable speed operation of wind turbines", Proc. of European Union Wind Energy Conference, Sweden, 1996, pp. 406-409.

14. A. Gangwar, "Comparative study of power electronic converters for wind energy conversion system", 2015 Annual IEEE India Conf. (INDICON), New Delhi, pp. $1-6,2015$.

15. I. Cadirci, M. Ermis, "Double-output induction generator operating at sub-synchronous and supersynchronous speeds: steady-state optimization and wind-energy recovery", IEE Proc B Electric Power Applications, 139 (1992):429-42.

16. F. Blaabjerg and K. Ma, "Future on power electronics for wind turbine systems", IEEE J. Emerg. Sel. Topics Power Electron, vol. 1, no. 3, pp. 139-152, Sep. 2013.

17. Rishabh Dev Shukla, R.K. Tripathi\& S. Gupta,"Power electronics applications in wind energy conversion system: A review", IEEE International Conference on Power, Control and Embedded Systems (ICPCES), 2010 organized during Nov 29- Dec 01, 2010 at MNNIT Allahabad (ISBN:978-1-4244-8543-7).

18. Venktesh Mishra, Mr. Premnath Gupta and Dr Rishab Dev Shukla, "Performance Analysis of Autonomous DFIM based wind energy generation system", Published in, International Journal of Electronics and Device Physics,(Publisher: VIBGYOR ePress), Vol. 3 [ISSN: 2631-5041]. 
19. A. K. Jain, "Control of stand-alone variable speed generation system using wound rotor induction machine", M.S. (Engg.) thesis, Dept. Elect. Eng., IISc Bangalore, Bangalore, India, Dec. 2004.

20. G. Iwanski, W. Koczara, "Island operation of the variable speed induction generator", Power Electronics and Motion Control Conference, 2004. IPEMC2004. 4th International, pp.896-901 Vol.2, 14-16 Aug. 2004.

21. A. Tapia, G. Tapia, J. X. Ostolaza, and J. R. Saenz, "Modeling and control of a wind turbine driven doubly fed induction generator," Energy Conversion, IEEE Transactions on, vol. 18, no. 2, pp. 194-204, 2003.

22. J. M. Espi, J. Castello, "Wind turbine generation system with optimized DC-link design and control", IEEE Trans. Ind. Electron., vol. 60, no. 3, pp. 919-929, Mar. 2013.

23. Rishabh Dev Shukla, Prof. R.K. Tripathi, "Isolated Wind Power Supply System using Double-fed Induction Generator for Remote Areas," Published in, Energy Conversion and Management (Publisher: Elsevier Science), [ISSN: 0196-8904].

24. L. Qizhong, Y. Lan, W. Guoxiang, "Comparison of control strategy for Double-Fed Induction Generator (DFIG)", Proc. 3rd ICMTMA, vol. 1, pp. 741-744, 2011.

25. Sudhakar. C. J, Diwakar. R. Joshi, "Design Aspects of Low Wind Speed Wind Turbines" IEEE International Conference on Electrical, Electronics, Computers, Communication, Mechanical and Computing (EECCMC), 2018.

26. P. K. Goel, B. Singh, S. S. Murthy, N. Kishore, "Modeling and control of autonomous Wind Energy Conversion System with Doubly Fed Induction Generator", Power Electron. Drives Energy Syst. 2010 Power India 2010 Jt. Int. Conf., pp. 1-8, 2010.

27. Rishabh Dev Shukla, \& Dr. R.K. Tripathi, "Speedsensorless Voltage \& Frequency Control in Autonomous DFIG based Wind Energy Systems", in Proc., 2014 IEEE Australasian University Power Engineering Conference (AUPEC2014), 28 Sep-01 Oct, 2014 Curtin University, Perth, WA, Australia.

28. Rishabh Dev Shukla, \& Dr. R.K. Tripathi, "A Standalone Wind Energy Conversion System Using wound rotor induction machine", in IEEE International Conference on Power, Energy and Control (ICPEC '13), Feb 06-08, 2013, DindigulTamilnadu. (ISBN: 978-14673-6028-9).

29. R.S. Pena, G. M. Asher, J.C. Clare, R. Cardenas, “A constant frequency constant voltage variable speed stand alone wound rotor induction generator", Opportunities and Advances in International Power Generation, 18-20March 1996, Conference Publication No. 419, IEEE, 1996, pp. 111-114.
30. Rishabh Dev Shukla \& Prof. R.K. Tripathi, "A Novel Voltage \& Frequency Controller for Standalone DFIG based Wind Energy Conversion System", Published in, Renewable and Sustainable Energy Reviews (Publisher: Elsevier Science), Vol. 37, September (2014) pp. 69-89 [ISSN: 1364-0321]. (Impact factor: 5.510).

31. Venktesh Mishra, Mr. Premnath Gupta, "Wind energy generation system using wound rotor induction machine", in 2019 IEEE International Conference on Innovations in Power and Advanced Computing Technologies (i-PACT), 22-23 March 2019.

32. Rishabh Dev Shukla, \& Dr. R.K. Tripathi, "Topologies for Stand-alone DFIG based Wind Energy Conversion System", 2nd IEEE International Conference on Power, Control and Embedded Systems (ICPCES), organized during Nov 15-16, 2012 at MNNIT Allahabad. (ISBN: 978-1-4673-1049-9).

33. E. Bogalecka, "Power control of a doubly fed induction generator without speed or position sensor", Proc. of EPE ‘93, Vol.8, 1993, pp. 224-228.

34. M Kaleeswari, M. Madheswaran, T Binshad, K. Vijayakumar, "A modified power electronic converter topology for stand-alone photovoltaic power generation system", 6th International Electric Drives Production Conference (EDPC) Nuremberg, pp. 158-163, 2016, 2016.

35. D.G.Forchetti, J.A.Solsona, G.O.Garcia, M.I.Valla,"A control strategy for stand-alone wound rotor induction machine", Electric Power Systems Research, vol.77, Issue2, Feb.2007, Pages 163-169.

36. PavlosTourou, Constantinos Sourkounis, "Review of control strategies for DFIG-based wind turbines under unsymmetrical grid faults", 9th International Conference on Ecological Vehicles and Renewable Energies (EVER), 2014,Pages: 1- 9.

37. L. Mihet-Popa, F. Blaabjerg, I. Boldea, "Wind Turbine Generator Modeling and Simulation Where Rotational Speed is the Controlled Variable", IEEE Transactions on Industry Applications, 2004, Vol. 40, No. 1. pp.3-10.

38. N.K.S. Naidu, B. Singh, "Grid-interfaced DFIG-based variable speed wind energy conversion system with power smoothening", IEEE Trans. Sustain. Energy, vol. 8, no. 1, pp. 51-58, Jan. 2017.

39. MR Dubois, H.Polinder, JA Ferreira, "Comparison of generator topologies for direct-drive wind turbines", Proc. Nordic Countries Power and Industrial Electronics Conf. (NORPIE), Aalborg, Denmark, June 2000, pp. 22-26.

40. D. Zhi and L. Xu, "Direct Power Control of DFIG with Constant Switching Frequency and Improved Transient Performance," Energy Conversion, IEEE Transactions on, vol. 22, no. 1. pp. 110-118, 2007.

41. Gil D. Marques, Matteo F. Iacchetti, "Sensorless Frequency and Voltage Control in the Stand-Alone 
DFIG-DC System", Industrial Electronics IEEE Transactions on, vol. 64, no. 3, pp. 1949-1957, 2017.

42. Zhong Wang, Yuanzhang Sun, Guojie Li, Xiong Li, "A Novel Control Strategy for DFIG Based on Magnitude and Frequency of Rotor Voltage for Wind Power Generation", Power and Energy Engineering Conference 2009. APPEEC 2009. Asia-Pacific, pp. 1-7, 2009.

43. Xin Hao, Chong Wei Zhang, Xing Zhang, Yong Yu, "A Novel Sensorless Control Strategy of Doubly Fed Induction Generator Based on Stator Voltage", Power and Energy Engineering Conference (APPEEC) 2010 Asia-Pacific, pp. 1-4, 2010.

44. G. Iwanski, W.Koczara,"Sensorless direct voltage control method for stand-alone slip-ring induction generator", Power Electronics and Applications, 2005 European Conference on, vol., no., pp.10 pp., P.10. doi: 10.1109/EPE.2005.219653.

45. S. Li, T. A. Haskew, K. A. Williams, R. P. Swatloski, "Control of DFIG wind turbine with direct-current vector control configuration", IEEE Trans. Sustain. Energy, vol. 3, no. 1, pp. 1-11, Jan. 2012.

46. K. C. Wong, S. L. Ho, and K. W. E. Cheng, "Direct control algorithm for doubly fed induction generators in weak grids," Electric Power Applications, IET, vol. 3, no. 4. pp. 371-380, 2009.

47. G. Xiao-Ming, S. Dan, H. Ben-Teng, and H. Ling-Ling, "Direct power control for wind-turbine driven doublyfed induction generator with constant switch frequency," Electrical Machines and Systems, 2007. ICEMS. International Conference on. pp.253-258, 2007.

48. L. Xu and P. Cartwright, "Direct Active and Reactive Power Control of DFIG for Wind Energy Generation," IEEE Transactions on Energy Conversion, vol. 21, no. 3, pp. 750-758, Sep. 2006.

49. SubirDatta, J. P. Mishra, A. K. Roy, "Active and reactive power control of a grid connected speed sensor less DFIG based wind energy conversion system", Energy Power and Environment: Towards Sustainable Growth (ICEPE) 2015 International Conference on, pp. 1-6, 2015.

50. R. Anilkumar, G. Devriese, A.K. Srivastava, "Voltage and reactive power control to maximize the energy savings in power distribution system with wind energy", IEEE Trans. Ind. Applicat., vol. 54, no. 1, pp. 656-664, Jan. 2018.

51. Venktesh Mishra, Mr. Premnath Gupta and Dr Rishab Dev Shukla,"A comparative study on instantaneous direct voltage and frequency control in WRIM based wind energy conversion system with and without speed sensor" in $4^{\text {th }}$ International Conference on Academic Research in Engineering, Management and Information Technology (ICAREMIT-2019), 16-18 April 2019.
52. Z. Boudries, D. RekiouaZiani, M. Sellami, "Direct power control of a PWM rectifier fed autonomous induction generator for wind energy applications", Energy Procedia, vol. 36, pp. 391-400, 2013.

53. Alameen K. Eberaheem,Wei Xu, Yi Liu, Mohamed G. Hussien, " Sensorless Direct Voltage Control based on MRAS Observer for the Stand-Alone Brushless Doubly-Fed Induction Generator", $2018 \quad 21^{\text {st }}$ International Conference on Electrical and System (ICEMS), October 7-10, 2018. Jeju, Korea.

54. E. Bogalecka, Z. Kmmiliski, "Sensorless Control of Double Fed Machine for Wind Power Generators" Int Conf. EPE-PEMC 2002, Cavtat\& Dubrovnik, 2002.

55. G. Iwanski, W.Koczara,"Extended Direct Voltage Control of the Stand-Alone Double Fed Induction Generator", Power Engineering, Energy and Electrical Drives, 2007 (POWERENG-2007), International Conference on, vol.31, no 2, pp.754-759, 12-14 April 2007. doi: 10.1109/POWERENG.2007.4380117

56. N. Krishna Swami Naidu, Bhim Singh, "Sensorless control of single voltage source converter-based doubly fed induction generator for variable speed wind energy conversion system," IET Power Electron. 2014, vol. 7, iss. 12 , pp. 2996-3006.

57. Y. Liu, W. Xu, J. Zhu and, F. Blaabjerg, "Sensorless Control of Standalone Brushless Doubly-Fed Induction Generator Feeding Unbalanced Loads in Ship Shaft Power Generation System", IEEE Transactions on Industrial Electronics, vol. 66, no. 1, pp. 739-749, May 2018.

58. B. Singh, NKS Naidu, "Direct power control of single VSC-based DFIG without rotor position sensor", IEEE Trans. Ind. Appl. 2014, 50, 4152-4163.

59. Venkata Rama Raju Rudraraju, ChilakapatiNagamani, SaravanallangoGanesan, "A Control Strategy for Reliable Power Output From a Stand-alone WRIG With Battery-Supported DC Link", Power Electronics IEEE Transactions on, vol. 32, no. 6, pp. 4334-4343, 2017.

60. D.Forchetti, G. Garcia, M. I. Valla, "Vector Control Strategy for a Doubly-Fed Stand-Alone Induction Generator"', IECON, Nov. 2002, vol. 2. pp.991-995

61. R.S. Pena, R.J. Cardenas, G.M. Asher, J.C. Clare, "Vector controlled induction machines for stand-alone wind energy applications", Industry Applications Conference, 2000. Conference Record of the 2000 IEEE, vol.3, no., pp.1409, 1415 vol.3, 2000. doi: 10.1109/IAS.2000.882069

62. M. Z. Sujod, I. Erlich, and S. Engelhardt, "Improving the reactive power capability of the DFIG-based wind turbine during operation around the synchronous speed," IEEE Trans. Energy Convers., vol. 28, no. 3, pp. 736-745, Sep. 2013.

63. Z. Chen, E. Spooner, "Voltage source inverters for high-power, variable-voltage dc power sources", Proc. 
Inst. Electr. Eng. Generation, Transmiss. Distrib, vol. 148, no. 5, pp. 439-447, Sep. 2001.

64. Rishabh Dev Shukla \& Prof. R.K. Tripathi, "Maximum Power Extraction Schemes \& Power control in Wind Energy Conversion System", International Journal of Scientific \& Engineering Research, Volume 3, Issue 6, June-2012 [ISSN: 2229-5518].

65. Shailendra Sharma, Bhim Singh, A. Chandra, K. AlHaddad, "Control of doubly fed induction generator in standalone wind energy conversion system", Industry Applications Society Annual Meeting 2015 IEEE, pp. $1-8,2015$.

66. M.F. Iacchetti, G.D. Marques, R. Perini, "A scheme for power control of DFIG connected to a dc-bus via a diode rectifier", IEEE Transactions on Power electronics, vol. 30, no. 3, pp. 1286-1296, March 2015.

67. Himanshu Mishra, AkhilaGundavarapu, Amit Kumar Jain, "Control Scheme for DC voltage Regulation of Stand-alone DFIG-DC system", IEEE Transactions on Industrial Electronics, vol. 64, no. 4, April 2015.

68. M.F. Iacchetti, G.D. Marques, "Voltage control in a DFIG-DC system connected to a stand-alone de load", proceedings 9th international conference Compat. Power Electronics, pp. 323-328, June 24-26, 2015.

69. N. K. Swami Naidu, Bhim Singh, "Experimental Implementation of a Doubly Fed Induction Generator Used for Voltage Regulation at a Remote Location", Industry Applications IEEE Transactions on, vol. 52, no. 6, pp. 5065-5072, 2016.

70. R. Zhu, Z. Chen, Y. Tang, F. Deng, X. Wu, "Dual-loop control strategy for DFIG-based wind turbines under grid voltage disturbances", IEEE Trans. Power Electron., vol. 31, no. 3, pp. 2239-2253, Mar. 2016.

71. Anjana Jain, Janardhan Reddy B, "Control of doubly fed induction generator connected to variable speed wind turbine", Advancements in Power and Energy (TAP Energy) 2015 International Conference on, pp. 500-505, 2015.

72. Mohammed L'Hadj Said, Samir Moulahoum, Mohamed Bounekhla, Nadir Kabache, Hamza Houassine, "Autonomous operation of a doubly fed induction generator driven by a wind turbine", Methods and Models in Automation and Robotics (MMAR) 2015 20th International Conference on, pp. 1050-1055, 2015.

73. SarojaKantiSahoo, SumanMondal, DebaprasadKastha, Avinash K. Sinha, N. K. Kishore, "Wind turbine emulation using doubly fed induction motor", 21st Century Energy Needs - Materials Systems and Applications (ICTFCEN) 2016, pp. 1-5, 2016.

74. D. Arsudis, W. Vollstedt, "Sensorless Power control of a Double-Fed AC-Machine with nearly Sinusoidal Line Currents”, Proc. of EPE '89, Aachen 1989, pp. 899-904.

75. A.K. Jain, V.T. Ranganathan, "Wound rotor induction generator with sensorless control and integrated active filter for feeding nonlinear loads in a stand-alone grid", IEEE Transaction on Industrial Electronics, vol. 55, No. 1, pp. $218-228,2008$.

76. V.S.S.P.K. Hari, A. Tripathi and G. Narayanan, "Experimental determination of mechanical parameters in sensorless vector-controlled induction motor drive", Sadhana, vol. 42, no. 8, pp. 12851297, Aug, 2017.

77. G.D. Marques, M.F. Iacchetti, "Stator frequency regulation in a field-oriented controlled DFIG connected to a dc link", IEEE Transactions on Industrial Electronics, vol. 61, no. 11, pp. 5930-5939, Nov. 2014.

78. AkhilaGundavarapu, HimanshuMisra, Amit Kumar Jain, "DC voltage regulation with field oriented control of WRIG-DC system feeding an isolated DC load", Power Systems (ICPS) 2016 IEEE 6th International Conference on, pp. 1-6, 2016.

79. Prerak Bhardwaj, K. Vijayakumar, "Modelling operation and speed estimation of standalone wind driven doubly fed induction generator", Inventive Systems and Control (ICISC) 2018 2nd International Conference on, pp. 185-190, 2018.

80. L. Morel, H. Godfroid, A. Mirzaian, J.M. Kauffmann, "Double-fed induction machine: converter optimisation and field oriented control without position sensor", Electric Power Applications, IEE Proceedings, vol.145, no.4, pp.360-368, Jul 1998. doi: 10.1049/ipepa:19981982.

81. S. Peresada, A. Tilli, and A. Tonielli, "Indirect stator flux-oriented output feedback control of a doubly fed induction machine", IEEE Trans. Control System Tech., vol. 11, no.6, pp. 875-88, 2003.

82. Raji R. Nair, G. Narayanan, "Modified model reference adaptive observer for rotor speed and position estimation in wound rotor induction machine, "published in IEEE PES Asia-Pacific Power and Energy IEEE PES Asia-Pacific Power and Energy Engineering Conference (APPEEC) 2017.

83. Rishabh Dev Shukla, Prof. R.K. Tripathi, "Dynamic Performance of DFIG based WECS under different Voltage Sag”, in International Journal of Chemtech research, Vol.5, No.2, pp. 980-992, April-June 2013.

84. Venktesh Mishra, Mr. Premnath Gupta, "Load Harmonics Compensation in Autonomous DFIG Based Wind Turbine Systems", in $3^{\text {rd }}$ International Conference and Workshops on Recent Advances and Innovations in Engineering (ICRAIE-2018), 22-25 November 2018 (IEEE Conference Record \# 43534).

85. Venktesh Mishra, Premnath Gupta, Rishabh dev Shukla, "Performance analysis of Autonomous DFIM based Wind Energy Generation System", in International Journal of Electronics and Device Physics 3:005,,ISSN: 2631-5041 DOI: 10.35840/2631-5041.

86. MonalisaPattnaik, DebaprasadKastha, "Unbalance and harmonic voltage compensation for a stand-alone 
variable speed constant frequency double-output induction generator supplying non-linear and unbalanced loads", Electric Power Applications IET, vol. 7, no. 1, pp. 27-38, 2013.

87. AdikandaParida, Debashis Chatterjee, "Model-based loss minimisation scheme for wind solar hybrid generation system using (grid-connected) doubly fed induction generator", Electric Power Applications IET, vol. 10, no. 6 , pp. 548-559, 2016.

88. MonalisaPattnaik, DebaprasadKastha, “Adaptive Speed Observer for a Stand-Alone Doubly Fed Induction Generator Feeding Nonlinear and Unbalanced Loads," IEEE Transactions on Energy Conversion, vol. 27, no. 4, pp. 1018-1026, Dec. 2012.

89. P. L. Jansen, R. D. Lorenz, and D. W. Novotny, "Observer-based direct field orientation: Analysis and comparison of alternative methods," IEEE Trans. Ind. Appl., vol. 30, no. 4, pp. 945-953, Jul./Aug. 1994.

90. I. Benlaloui, S. Drid, L. Chrifi-Alaoui, and M. Ouriagli, "Implementation of a new MRAS speed sensorless vector control of induction machine," IEEE Trans. Energy Convers., vol. 30, no. 2, pp. 588-595, Jun. 2015.

91. Ahmad Bashar Ataji, Yushi Miura, ToshifumiIse, Hiroki Tanaka, "A Rotor-Current-Based Slip Angle Estimator for Grid-Connected Doubly Fed Induction Generator Requiring the Stator Inductance Only," Published in IEEE Transactions on Power Electronics 2017 DOI:10.1109/TPEL.2016.2598441.

92. R. Pena, R. Cardenas,J.Proboste, G. Asher, J.Clare, "Sensorless Control of a Slip Ring Induction Generator based on Rotor Current MRAS Observer", Power Electronics Specialists Conference, 2005. PESC '05. IEEE $36^{\text {th }}$, pp.2508-2513, 16 June 2005. doi: 10.1109/PESC.2005.1581985.

93. I M. Koc, T. Sun, and J. Wang, "Performance improvement of direct torque controlled interior mounted permanent magnet drives by employing a linear combination of current and voltage based flux observers," IET Power Electron., vol. 9, no. 10, pp. 2052-2059, 2016.

94. Alameen K. Ebraheem, Wei Xu, Yi Liu, Mohamed G. Hussien, "Sensorless Direct Voltage Control Based on MRAS Observer for the Stand-Alone Brushless Doubly Fed Induction Generator", 2018 21st International Conference on Electrical Machines and Systems (ICEMS-2018).
95. L. Lu, N. F. Avila, C. Chu and T. Yeh, "Model reference adaptive back electromotive-force estimators for sensorless control of grid-connected DFIGs," IEEE Transactions on Industry Applications, vol. 54, no. 2, pp. 1701-1711, March-April 2018.

96. Z. Yin, Y. Zhang, C. Du, J. Liu, X. Sun, and Y. Zhong, "Research on antierror performance of speed and flux estimation for induction motors based on robust adaptive state observer," IEEE Trans. Ind. Electron., vol. 63, no. 6, pp. 3499-3510, Jun. 2016.

97. Verghese, C. George, S.R. Sanders, "Observers for flux estimation in induction machines", Industrial Electronics, IEEE Transactions on, vol.35, no.1, pp.85, 94, Feb 1988. doi: 10.1109/41.3067.

98. MonalisaPattnaik, DebaprasadKastha, "Reactive power based MRAS observer for speed sensorless control of double output induction generator", Industrial and Information Systems (ICIIS) 2010 International Conference on, pp. 556-561, 2010.

99. Kris Scicluna, Cyril Spiteri-Staines, Maurice Apap, "Analysis of harmonics on a MRAS system used for sensorless control of a DFIG", Power Electronics and Applications (EPE) 2013 15th European Conference on, pp. 1-12, 2013.

100. Kris Scicluna, Cyril Spiteri-Staines, Maurice Apap, "MRAS observers for Doubly-Fed Induction Machine in wind energy conversion systems", EUROCON 2013 IEEE, pp. 882-888, 2013.

101. Adel Mehdi, AbdellatifReama, HocineBenalla, "MRAS observer for sensorless direct active and reactive power control of DFIG based WECS with constant switching frequency", Ecological Vehicles and Renewable Energies (EVER) 2016 Eleventh International Conference on, pp. 1-7, 2016.

102. Lin-Yu Lu, Chia-Chi Chu, Tzu-Wei Yeh, "Model reference adaptive back-EMF estimations for sensorless control of grid-connected doubly-fed induction generators", Industry Applications Society Annual Meeting 2016 IEEE, pp. 1-8, 2016.

103. M. Pattnaik, D. Kastha, "Comparison of MRAS based speed estimation methods for a stand-alone Doubly Fed Induction Generator", Energy Automation and Signal (ICEAS) 2011 International Conference on, pp. 1-6, 2011. 